\title{
Community Empowerment Through Optimization of Geographic Indication (A Study on Local Products in Tambakroto Village, Sayung District, Demak Regency )
}

\author{
M Shidqon Prabowo ${ }^{1}$ \\ ${ }^{1}$ Faculty of Law, Universitas Wahid Hasyim Semarang \\ Received January 01 2018, Accepted April 22 2019, Published May 312019
}

DOI 10.15294/jg.v16i1.17748

\begin{abstract}
Geographical Indication is a sign used on goods that have a specific geographical origin and has the quality or reputation is based on place of origin. In general, Geographical Indications is the name of the place of origin of such goods. Agricultural products typically have qualities that are formed from the place of production and are influenced by local factors are specific, such as climate and soil. Sub Tambakroto Sayung is one of the District in the city of Demak, which has the potential for geographical indications. The potential of geographical indications which are owned by the city of Demak District Tanbakroto Sayung has geographic conditions, natural resources, agricultural products, crops, and cultural traditions. This article is based on research which aims to record the superiority of geographical indications held by Demak Regency and to analyzing supporting and inhibiting factors in empowering the advantages of geographical indications.
\end{abstract}

Keyword: Community Empowerment; Geographical Indications

\section{INTRODUCTION}

Geographical Indication is a sign that is used on goods that have a specific geographical authenticity and have a quality or reputation based on the place of origin. In general, the Geographical Indication is the place name of the origin of the items. Agricultural products usually have qualities that are formed from their production sites and are influenced by specific local factors, such as climate and soil. Based on this provision, it is understood that the origin of an item (of course, actually including services) that is attached to a reputation, the characteristics and quality of an item associated with a particular area are legally protected.

Agricultural and food products have been associated with unique quality attributes associated with agroecological characteristics and culinary traditions of their origin ${ }^{1}$. Products that can be characterized by geographical indication protection are: a) agricultural products (due to natural factors including weather, soil texture, temperature, etc.). For example, Brasmati rice, Delanggu rice, Brebes Salted Egg, West Sumatra Gambir, etc., b) Handicrafts and certain industrial products (related to HR who have special expertise that is crucial in the production and manufacturing process). Examples of Jepara carved furniture, Juwana Brass Crafts, and others.

The existence of geographical indication rights in an area cannot be ignored, or even considered to have no direct benefits for welfare, but on the contrary, it must be protected and empowered optimally because it turns out has great potential to improve the welfare of the community ${ }^{2}$. With the presence of IG products, the

1 Deselnicu, et al., 2013, A Meta-Analysis Geographical Indication Food Valuation Studies: What Drives the Premium for Origin-Based Labels?, Journal of Agricultural and Resource Economics, page 216.

2 Sumiyati, Yeti, ect., 2008, Kajian Yuridis Sosiologis mengenai Indikasi Geografis sebagai Sumber Pendapatan Asli Daerah *E-mail :Shidqonhamzah@yahoo.com

Address : Jl. Menoreh Tengah VII No.X no 22, Sampangan,

Gajahmungkur, Semarang City, Central Java 50232 
reputation of an IG region will naturally be lifted, on the other hand IG can also preserve the beauty of nature, traditional knowledge, and biological resources, and this will have an impact on the development of agrotourism, with IG also stimulating the emergence of other activities related ones such as further processing of a product. All economic activities due to the Geographical Indications will automatically contribute to the economy of the IG and the protection itself (Yessiningrum, 2015: 47). In addition, through optimal IG protection not only is environmental sustainability expected to be maintained, but the empowerment of natural and human resources in the areas expected can also be maximized ${ }^{3}$

Basically, Geographical Indications protect agricultural products, processed products, handicrafts, or other goods whose qualities and characteristics are influenced by the geographical environment as soon as possible. That is, there is a relationship or link between the product where the product originates. The area of Tambakroto village Sayung District of Demak has a huge potential to geographical indications. Potential regarding geographical indications held by Tambakroto Village, Sayung District, Demak Regency this is found in geographical conditions, natural wealth, agricultural products, plantation products and cultural traditions that exist. Therefore, it is appropriate if the researcher tries to explore and record the geographical indications possessed by Tambakroto Village, Sayung Subdistrict, Demak Regency by conducting a study.

\section{RESEARCH METHODS}

The method used in this research is the socio-economic juridical method. The use of this method is related to the specifications that would be revealed by researchers in this study. The researcher in searching the research data was conducted in a socio-economic juridical starting from the primary data obtained in the field based on legislation, a socio-cultural community in the research area and the impact of the subject of economic research for the community at the research location.

The specifications in this study are to explore and reveal and record local products that are on Tambakroto Village Sayung Subdistrict Demak Regency has the potential as a product that has geographical indications so that these products will be empowered so that they have strong competitiveness with products from other similar regions. This study regarding geographical indications was carried out at Tambakroto Village, Sayung District, and Demak Regency. Selected Tambakroto Village, Sayung District, Demak Regency as the location of the study based on various considerations from the research team. One consideration for conducting research in Tambakroto Village, Sayung District, Demak Regency is that Tambakroto Village, Sayung District, Demak Regency has the potential for natural wealth, the potential for agriculture, plantations, potential fisheries and small and medium enterprises that process natural wealth.

The method used in this study is purposive sampling method, which is taking samples with certain considerations that are in accordance with the criteria that have been determined and always basing themselves on information and knowledge that has been obtained or checked with specific characteristics of a population ${ }^{4}$. In retrieving data, researchers took interview techniques and literature studies. To guarantee the validity of the data obtained in this study, the collected data will be checked for truth through triangulation methods ${ }^{5}$. This triangulation method is used with the aim of comparing the same data from different sources or at different times from the same source.

\section{RESULT AND DISCUSSION}

Tambakroto Village, Sayung District is the conservation area for Demak district. Therefore the development carried out in the area of Tambakroto Village, Sayung District must be based on the Tatak Room of the Demak Regency. In general, Tambakroto Village, Sayung District, Demak Regency can be seen in the administrative data obtained by the research team. Based on the results of the study obtained data until April 2016, the administrative village of Tambakroto with an area 405,7150 Ha with a population reaching 2,814 or 794 households collected from 10 RWs and 20 RTs. Based on the topographical conditions, Tambakroto village at the time of $259 \mathrm{~m}$ above sea level. So with this condition, the majority of Tambakroto village areas function as conservation land. Tambakroto Village is the village area of the state is, where the Tambakroto village has an area bordering on other districts in the district of Sayung Regency Demak. The boundaries of the Batakroto

(PAD), Mimbar Journal, Vol. 24, No. 1, page 87.

3 Asfiyah, 2015, Perlindungan Hukum Potensi Indikasi Geografis di Kabupaten Brebes Guna Pengembangan Ekonomi Masyarakat Lokal, Jurnal Idea Hukum, Vol. 1, No. 2, page 113.

4 Soemitro, Ronny Hanitijo, 1988, Metodologi Penelitian Hukum ddan Jurimetri, Jakarta: Ghalia Indonesia, page 116.

5 Nasution, 1992, Metode Penelitian Naturalistik. Bandung: Tarsito, page 115; Miles, Matthew B dan A. Michael Huberman. 1992. Analisis Data Kualitatif. Terjemahan Tjetjep Rohendy Rohidi. Jakarta: UI Press., page 434. 
village in Sayung Regency, Demak are as follows: West Side: Sayung Village /Village, North Side: Loireng Village /Village, East Side: Pilangsari Village /Village, South Side: Prampelan Village /Village.

Based on the condition of the region, the Tambakroto village in Sayung district is very suitable for the plantation, agriculture and industrial areas. With these conditions, the business in the field of agriculture and agriculture became the main foundation as a source of community income. Based on data obtained during the conduct of research activities, data can be obtained from 4 (four) a large majority of the livelihoods of residents in the village of Tambakroto Kecamayan Sayung. The data is Buruh Tani as many as 6,636 residents or as much as $24.69 \%$, Building Labor as many as 5,541 people or $20.61 \%$, then Landowners Farmers as many as 4,856 people or $18.07 \%$ and Farmers as many as 3,725 people or $13,86 \%$. Data obtained from these data that the majority of the population in district village Sayung Tambakroto is as laborers, both farm laborers, and industrial workers and as landowners and only $18.07 \%$ only. Complete information on population livelihood data in Tambakroto will be presented in full in Table 1 below.

Table 1. Population According to Job

\begin{tabular}{clrr}
\hline No & \multicolumn{1}{c}{ Job } & Number of people) & Percentage (\%) \\
\hline 1 & Landowner Farmers & 4.856 & 18,07 \\
2 & Farmworkers & 3.725 & 13,86 \\
3 & Fisherman & 15 & 0,06 \\
4 & Medium / Large Entrepreneurs & 462 & 1,72 \\
5 & Small Craftsmen / Industries & 193 & 0,72 \\
6 & Industrial Workers & 6.636 & 24,69 \\
7 & Construction workers & 5.541 & 20,61 \\
8 & Mining Workers & 16 & 0,06 \\
9 & Plantation Workers (Large + Small) & 298 & 1,11 \\
10 & Traders & 1.693 & 6,30 \\
11 & Transportation & 246 & 0,92 \\
12 & Civil Servants (PNS) & 1.919 & 7,14 \\
13 & ABRI & 308 & 1,15 \\
14 & Retired (PNS / ABRI) & 453 & 1,69 \\
15 & Dairy Cow Farmers & 135 & 0,50 \\
16 & Ordinary Cow Farmers & 75 & 0,28 \\
17 & Buffalo Breeders & 95 & 0,35 \\
18 & Goat Farmers & 197 & 0,73 \\
19 & Sheep Breeders & 15 & 0,06 \\
\hline & Total & $\mathbf{2 6 . 8 7 8}$ & $\mathbf{1 0 0}$ \\
\hline
\end{tabular}

Source: Monograph data of Tambakroto village, Sayung District, Semester II, 2018 from the data obtained, cassava and corn plants are the main crops planted by residents in the village of Tambakroto, Sayung district, followed by fruit trees. Regarding the types of plants or types of plants that are planted as livelihoods, they will be presented in the following table 2.

Table 2. Main Plant Production Area

\begin{tabular}{clrrrr}
\hline No & \multicolumn{1}{c}{ Type } & Plant Area & $\begin{array}{c}\text { Harvested Area } \\
(\mathbf{H a})\end{array}$ & $\begin{array}{c}\text { Production Average } \\
(\mathbf{H a})\end{array}$ & \multicolumn{1}{c}{ Total } \\
\hline 1 & Corn & 20,50 & 11,90 & 12 & 100 \\
2 & Cassava & 340,50 & 35 & 28 & 135 \\
3 & Sweet potatoes & 35 & 25 & 24 & 125 \\
4 & Fruits & 290 & 30 & 16,50 & 115,40 \\
\hline
\end{tabular}

Source: Monographical Data of Tambakroto Village, Sayung District, Semester II, 2018 Sayung subdistrict territory Tambakroto village has a dominant plantation crop, is Guava plant. Based on the monograph data that has been obtained, then the data obtained is only data about Guava plants only, while the other plants have no empirical data. planting guava in rural areas Tambakroto Sayung district, as in table 3. Here. 
Table 3. Area and yield of Guava

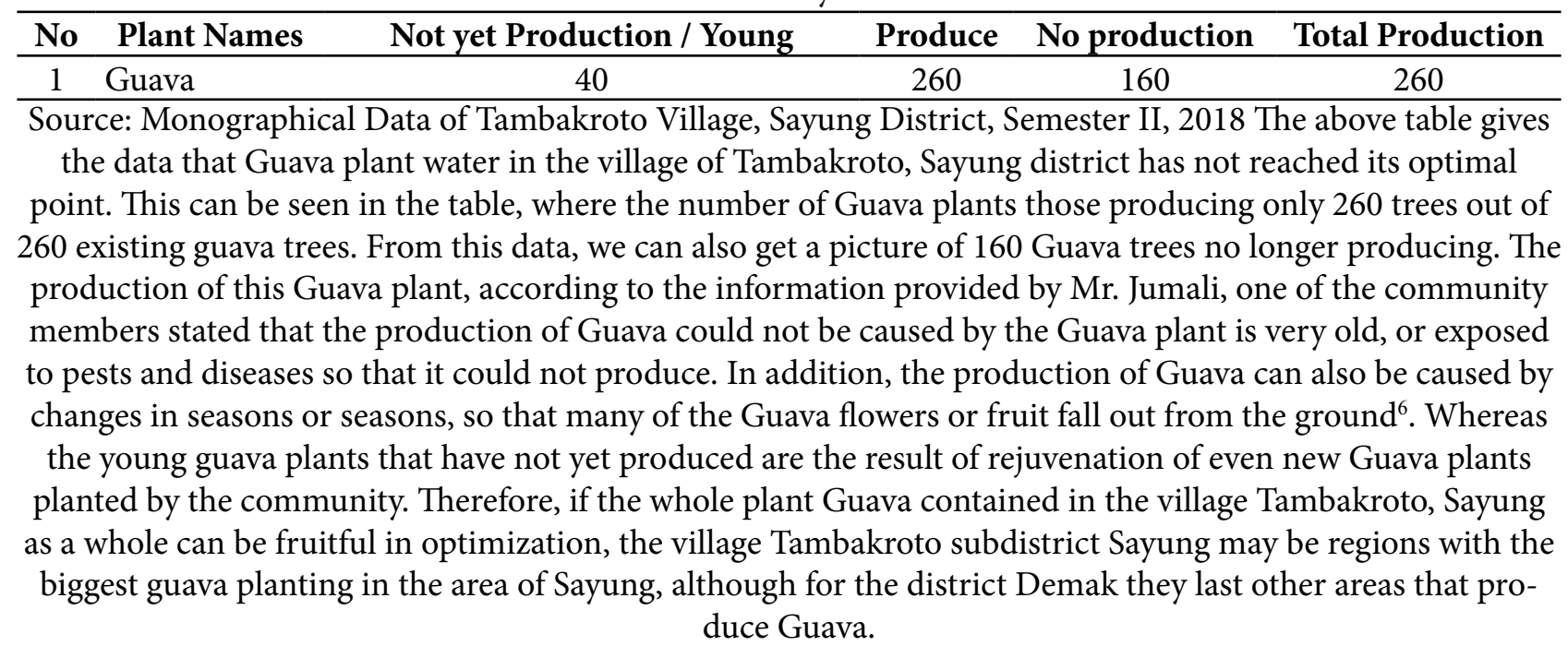

\section{The Potential of Geographical Indications owned by Tambakroto Village, Sayung District, Demak Regency}

Sayung Subdistrict is one of the districts in Demak Regency which has potential in developing geographical indications. This potential can be seen with the types of fruits that are famous in Demak Regency and centered on Sayung Subdistrict, namely Guava and Corn fruit. These plants can be regarded as geographical indications because they are well-known and they are Guava Sayung and Guava Sayung. The mention indicates that the Guava and corn originated from the Sayung District of Demak Regency. With the advantage in plantation, which is pretty much potential of guava plants in the area of Sayung District, then the water can be used as a potential Guava geographical indications.

Tambakroto village district territory of Sayung that as a guava plant still be evenly Demak regency is an area potential l guava plantation. Even the Tambakroto area of Sayung Subdistrict is an area of Guava production for Demak Regency. From the results of this information, the research team conducted secondary data excavation, namely in the form of library data. Based on the search of library data conducted by the research team, there is no single literature that can provide information that Tambakroto has the potential for geographical indications. The data obtained during the research only stated that the plants that mostly grow in Tambakroto are Guava plants.

The geographical indication potential in the form of Guava is supported by the fact on the ground that the entire area in the Sayung district has Guava trees. The existence of Guava trees in each of this village is supported by statements from each community leader in each village. Guava is the main cash crop. The number of Guava plants in Tambakroto is because the area is very suitable for Guava plants. The dominant safe plant in Tambakroto in the form of Guava plant and corn is inseparable from the condition of the area from the Tambakroto in the district of Sayung in general, which in the past was a community-owned plantation area in the form of Guava and Corn. The current time development, in which the Tambakroto region has transformed into a fairly rapid residential area along with the existence of factories and small housing estates, so many Guava and J Agung plantations have changed function to become residential housing areas. The change in land in this class will have an impact on the reduced potential possessed by Tambakroto village in the field of geographical indication.

The dominant threat in the Prampelan urban area is Guava and corn. Sub-village Committees Pilangsari, have specific characteristics that are different from other villages in the District Sayung. A distinctive feature possessed by the Pilangsari village is the potential for natural and cultural potential to improve the welfare of its people. These natural potentials are then developed and become assets to improve the welfare of the community in addition to plantation crops in the form of Guava and Corn. Sub-village Committees Pilangsari already developed a natural potential possessed by processing natural products owned into products that have added value such as molten metal processing of wood tuber, the hood of food manufacture of signs, etc. The development of the Pilangsari village has been set based on existing natural conditions. Besides that, the community here also develops mango trees to increase people's income. The utilization of natural potential to improve community

$6 \quad$ Has an interview, dated 18 April 2018 
welfare has been carried out for a long time. This regional election is different from other villages, so the community has long been optimizing the existing natural potential, namely Kreo Cave as a tourism asset that can improve the welfare of the community.

Loireng village Subdistrict of Sayung still has wider Guava and corn plants than other villages. The vast extent of Guava and corn plantations is due to the slow development of the village so that not many lands owned by residents change function. The slowness in the development of the Loireng village is due to the fact that the area is far from factories and small housing estates so that the village did not experience very significant changes as to what happened in the villages of Tambakroto Village and its surroundings. A large number of Guava and Corn fruit plants in the Loireng village. Had difficulties $n$ in selling the crop more than Guava, if the harvest comes the Guava produced numerous and abundant, but the fruit is not durable with corn so that if it is not sold then more of their own consumption than will a lot of rot and loss.

Guava originating from the Sayung Subdistrict area is not as big as Guava Semarang but Guava Sayung is sweet and very legit. Water apple Sayung has an advantage that is not inferior to Guava Semarang. The Guava plant can last a long time when compared to the Semarang Guava plant. Besides Guava plants Sayung also produces a lot of fruit when compared to Guava Semarang. Therefore, it is necessary to preserve and develop Guava which ultimately makes the Guava in the Sayung district able to become a superior product in enhancing the welfare of the community. In addition, this Guava is expected to be a product of the geographical Indications owned by Sayung district.

With a variety of potential Geographical Indications to increase economic growth in the community, the government should provide protection, with the intention of providing a way to avoid the use of Geographical Indications in any way, by giving signs or displaying items that can indicate or portray the goods being traded as originating from geographical area that is not from the actual place of origin (Ramli \& Sumiyati, 2015: 35). The protection of geographical indications has a variety of benefits, both for producers and for consumers. For producers, the benefits of geographical indications from the economic side include: (1) preventing the transfer of ownership rights to the use of product distinctiveness from the local community to other parties, (2) maximizing value-added products for local communities, (3) providing protection from product counterfeiting, (4) increase marketing typical products, (5) increasing the supply of employment, (6) supporting the development of agrotourism, (7) ensuring business sustainability, (8) strengthening regional economy, (9) accelerating regional development, (10) improving community welfare. In terms of ecology, geographical indications provide benefits including (1) maintaining and preserving nature, (2) enhancing regional reputation, (3) maintaining the sustainability of plasma nullah. Whereas from the socio-cultural side, geographical indications provide benefits including (1) strengthening relations between planters, (2) improving regional dynamics, (3) preserving customs, knowledge and local wisdom of the community. If viewed from a legal aspect, the geographical indication provides benefits including (1) providing quality assurance in accordance with consumer expectations of geographical indication products, (2) providing legal guarantees to consumers that protection against geographical indications is recognized and applies internationally.

Geographical indication as part of intellectual property has economic potential to provide added value to the region and will significantly impact the increase in product selling prices who obtain geographical indication protection ${ }^{7}$. Geographical indications can protect and utilize natural wealth for the welfare of local communities. Because in geographical indications it contains economic rights for local people. Economic rights are the right to manage and utilizing geographical indications which has a purpose for the welfare of the local community ${ }^{8}$. Seeing the benefits that can be obtained from the geographical indication in an area, it is expected that the regions in Indonesia can take advantage of the advantages of the geographical indications they have. As one of the districts in Demak Regency that has the potential for geographical indications, it is proper that the potential in Sayung district in the form of Guava is worked out seriously, both physically and in terms of legal protection.

To be able to take advantage of their profit potential of a geographical indication, then there are some important things that must be prepared, namely: (1) an understanding on the protection of geographical indications include benefits, processes, requirements, and challenges. This is done by the government, governors and regents/mayors to all related actors, (2) policies and consistency of government support, governors, regents/ mayors to provide protection for geographical indications for their regional specialty products, (3) prepare groups of officers and personnel experts to a) identify a typical product, b) recognize market inquiry perms for a typical product, c) recognize the causes of product distinctiveness, d) develop product specificity techniques,

7 Ayup Suran Ningsih, 2019, Indikasi Geografis atas Carica Dieng sebagai Strategi Penguatan Ekonomi Daerah, Suara Hukum Journal, Vol. 1, No. 1, page 116.

8 Yuli Prasetyo Adhi, etc., 2019, Membangun Kesejahteraan Masyarakat Lokal Melalui Perlindungan Indikasi Geografis, Meta-Yuridis Journal, Vol. 2., No.1, page 1. 
e) determine the boundaries of typical product producing areas, $\mathrm{f}$ ) increase farmers' knowledge to guarantee product distinctiveness, g) grow and improve farmer institutions to be able to manage products typical, h) produce a typical product specification book and boundary book, i) promote and market geographical indication products, $j$ ) protect geographical indication products and protect geographical indications. (4) increase farmers' knowledge, as well as grow and strengthen farmer groups by working groups and related work units, (5) request geographical indication protection to the Ministry of Law and Human Rights, (6) promote and market geographical indication protection and geographical indication products by owners Geographical indications are assisted by related work units and officers and experts, (7) protect the geographical indication protection and geographical indication products by geographical indication owners assisted by related work units and groups of officers and experts.

The need to develop and protect the Geographical Potential Potential is to: (1) maintain a product-specific identity; (2) is one of the marketing strategies in global competition; (3) protect the specific identity of the product from imitation. The strategy for developing and protecting bro can be done by : (1) strengthening the IKM / UKM 9 so that a cluster is formed ; (2) confirms the specific identity of the product ; (3) agree on protection whether owned by the regional government or cluster; (4) seek the existence of a trademark/label that shows the community/cluster; (5) attach the PIG label if it has been obtained.

\section{Policy in Opportunizing Geographical Indications}

Five factors that are the strengths for the development of Guava agribusiness are: (a) the availability of land supported by comparative advantage of agroecological conditions, (b) the superior nature of Guava for regional and national markets, (c) the availability of human resources and community support Superior Guava, (d) facilities / infrastructure and supporting institutions whose commitment is high to Guava forestry and its processing industry, (e) very large market potential. Some of the weaknesses that stand out are: (a) the gap results of research with commercial application, (b) position "Lembaga marketing" is very dominant, (c) has not been established linkages unequal partnership between principals of community forests Cashew water distribution system Guava, (d) marketed products are still limited to fresh fruit, (e) the high component of transportation costs in the structure of production costs.

Some of the opportunities that can be identified are: (a) domestic (local, regional and national) markets are very open, (b) diversification of potential Guava processed products, (c) the need to develop linkages between production clusters and distribution clusters in guava institutions integrated water, (d) the need to empower the institutional production system. Threats are taken seriously are (a) the constraints of distribution/trade Guava system, (b) competition with products imported fruits, especially fruits Guava, (c) the competition with other commodities in land use, (d) barriers to the Guava processing industry system.

Regarding the policies carried out by the village of Tambakroto, Sayung Subdistrict, in developing potential geographical indications in the Tambakroto village area, Sayung Subdistrict, even though they have been slightly mentioned in writing in the vision and mission, but the policy has not fully led to the concrete development of potential geographical indications. in the region Tambakroto village Sayung district.

Tambakroto Village, Sayung Subdistrict has not taken a more serious step in developing and optimizing the potential of geographical indications in the region Tambakroto village Sayung Subdistrict itself because previously understanding of the potential of geographical indications was not yet fully understood by Tambakroto village, Sayung Subdistrict community. This is the biggest obstacle to the development of these geographical indications. Based on these provisions, the policy in the village of Tambakroto, Sayung District can be made with the intention of facilitating the registration of geographical indication products and supporting their registration.

The policy adopted in optimizing geographical indications is by building facilities and infrastructure needed by the community and accommodating the aspirations that develop in the community. Aspirations and proposals from the developing community are proposals to collaborate with investors and the government in Demak district. Based on the results of the study, it was obtained information that one form of cooperation undertaken by the community in Sayung district was to plant 5 ha of Monthong Guava in the Prampelan village. This collaboration was carried out between the government of Demak district and the government of Semarang city. Cooperation between the government district of Semarang Demak with his government has been implemented since 2003. In addition to these policies, the other policies pursued by the government of the districts Demak, especially by the Department of Agriculture the districts Demak is the rejuvenation of the trees that have Guava old by replacing it with new Guava seeds and optimizing the existing Guava plants. Besides that, the 9 Indonesia term for small entreprises 
village in the Sayung district also has its own program in an effort to improve the welfare of the community by looking at excellence from each village area. Especially for Prampelan villages, besides planting Guava seeds as well as encourage the planting of other fruit trees such as mangoes and guava as secondary plants. Crop growers of mango and guava to anticipate when the water Cashew crops they have not $d$ a pat fruitful optimally, therefore, can not provide revenue as expected. With this replacement plant, it is expected that the community will still be able to obtain income from their plantation. In addition to mango plants and water herbs, the Prampelan village also developed Longan plants as secondary plants besides Guava with the same purpose.

While the Village Pilangsari further optimizes the potential of entrepreneurs in their area existing frame, which will be developed. Meanwhile, the Tambakroto urban village is running a regional structuring program with the narrower area of fruit trees in its area.

Regarding the policy in accordance with the commitment of Sayung Subdistrict that the vision of Sayung Subdistrict is to rely on agriculture and can also be seen in the Sayung Subdistrict mission where efforts to preserve the environment and Sayung Subdistrict strive to provide superior types of seeds, empower the community for technical/correct and good way of planting. The policy taken in efforts to empower the community through optimization of geographical indications was realized from the efforts of Sayung Subdistrict to facilitate the community by providing various kinds of superior seeds and not only that but the Sayung Subdistrict also tried to do empowerment through related institutions to empower the community for technical or ways good immersion.

The Sayung District policy has not yet reached the level of making the public understand the potential geographical indications possessed by Gungungpati Subdistrict itself but merely providing seeds and empowering them by means of good planting. The existing seeds are not synchronized with the potential geographical indications that have been owned by the Sayung Subdistrict so that this will kill the potential. The seeds that are not necessarily able to be planted in the Sayung Subdistrict area because they have to be adjusted according to the structure of the land from Sayung Subdistrict whether it is suitable or not with the seeds.

\section{CONCLUSION}

The geographical indication potential that has been owned by the village of Tambakroto, Sayung Subdistrict can now be said to be almost extinct. The near extinction of this potential geographical indication is caused by various factors. One factor is that the community no longer maintains and develops these potential indications for various reasons, especially economic factors. Besides that, the change in land function also triggers the near extinction of potential geographical indications in the Tambakroto village area of Sayung District.

The policy taken in an effort to improve the welfare of the community is by cooperating with investors or third parties who have attention to the existence of potential geographical indications in the village of Tambakroto, Sayung District. In addition to cooperating in developing potential geographical indications, it also supports a rejuvenation policy for plants that have the potential of geographical indications such as Guava. Another policy that can be taken is to carry out diversification of plants, especially fruit plants such as Guava plants, lo, and mango. This policy of diversifying fruit trees is in accordance with the policies of the village of Tambakroto, Sayung District Government who tried to make the Tambakroto village in Sayung district as a conservation area, especially the fruit gun plant to improve the welfare of the community.

Recommendations : (1) the need to carry out accurate and comprehensive data collection on potential geographical indications in the village of Tambakroto, Sayung district ; (2) an accurate database is made on all potential indications in the village of Tambakroto, Sayung Subdistrict ; (3) the need for consistent and continuous policies in the development of geographical indications in the Tambakroto village of Sayung district in particular the Demak district in general.

\section{BIBLIOGRAPHY}

\section{Books:}

Ashsofa, Burhan, 2001, Metode Penelitian Hukum, Jakarta: Rineka Cipta

Fauzan, Achmad, 2004, Perlindungan Hukum Hak Kekayaan Intelektual, Bandung: Yrama Widya

Lindsey, Tim., dkk, 2006, Hak Kekayaan Intelektual (Suatu Pengantar), Bandung: Alumni

Miru, Ahmadi, 2005, Hukum Merek: Cara Mudah Mempelajari Undang-undang Merek, Jakarta: RajaGrafindo Persada

Miles, Matthew B and A. Michael Huberman, 1992, Analisis Data Kualitatif. Translation by Tjetjep Rohendy Rohidi, Jakarta: UI Press. Nasution, 1992, Metode Penelitian Naturalistik. Bandung: Tarsito

Purwaningsih, Endang, 2005, Perkembangan Hukum Intellectual Property Rights, Bogor : Ghalia Indonesia

Purba, Achmad Zen Umar, 2005, Hak Kekayaan Intelektual Pasca TRIPs, Bandung: Alumni 
Saidin, OK., 1995, Aspek Hukum Hak Kekayaan Intelektual, Jakarta: RajaGrafindo Persada

Sjahputra, Iman, 2007, Hak Atas Kekayaan Intelektual (Suatu Pengantar), Jakarta: Harvindo

Soemitro, Ronny Hanitijo, 1988, Metodologi Penelitian Hukum ddan Jurimetri, Jakarta: Ghalia Indonesia

Usman, Rachmadi, 2003, Hukum Hak Atas Kekayaan Intelektual Perlindungan dan Dimensi Hukumnya di Indonesia, Bandung: Alumni

Journal :

Adhi, Y. P., and D. Sulistianingsih and V.N.S.Putri, 2019, Membangun Kesejahteraan Masyarakat Lokal Melalui Perlindungan Indikasi Geografis, Meta-Yuridis Journal, 2(1).

Asfiyah, Siti, 2015, Perlindungan Hukum Potensi Indikasi Geografis di Kabupaten Brebes Guna Pengembangan Ekonomi Masyarakat Lokal, Jurnal Idea Hukum, 1(2): 111-124.

Deselnicu, et al., 2013, A Meta-Analysis Geographical Indication Food Valuation Studies: What Drives the Premium for Origin-Based Labels?, Journal of Agricultural and Resource Economics, 38 (2): 204-219.

Ningsih, A. S., Waspiah, W., \& Salsabilla, S., 2019, Indikasi Geografis atas Carica Dieng sebagai Strategi Penguatan Ekonomi Daerah, Suara Hukum Journal, 1(1): 105-120.

Ramli, Teti A., and Yeti Sumiyati, 2009, Model Integrasi Lembaga Perwakilan Untuk Pendaftaran Sebagai Alternatif Pendaftaran Untuk Memperoleh Perlindungan Hukum Indikasi Geografis Ubi Cilembu, Jurnai Hukum dan Pembangunan, 39(1): 14-37.

Ramli, Teti A., and Yeti Sumiyati, 2015, Penyuluhan Tentang Perlindungan Hukum Indikasi Geografis Beras Pandanwangi Cianjur Jawa Barat Sebagai Wujud Sumbangsih Unisba Dalam Meningkatkan Indeks Pembangunan Manusia (LPM), Dharmakarya: Jurnal Aplikasi Ipteks untuk Masyarakat, 4(1): 27 - 36

Sumiyati, Yeti, ect., 2008, Kajian Yuridis Sosiologis mengenai Indikasi Geografis sebagai Sumber Pendapatan Asli Daerah (PAD), Mimbar Journal, 24(1): 79-88.

Yessiningrum, Winda Risna, 2015, Legal Protection on Geographical Indication as A Part of Intellectual Protection Rights, Jurnal Ius, $3(7): 42-53$. 